\title{
Professionalisering van ervaringsdeskundigen in de ggz: kans of risico?
}

\author{
Wilma Boevink
}

Published online: 30 October 2018

(C) Bohn Stafleu van Loghum is een imprint van Springer Media B.V., onderdeel van Springer Nature 2018

\begin{abstract}
Ervaringsdeskundigen dreigen ingezet te worden als goedkope arbeidskrachten in de ggz. Ze worden geacht 'productie te draaien' in een-op-eencontacten met cliënten. Het is de vraag of deze contacten, peer support of maatjescontacten genoemd, tot hun recht komen. Ervaringsdeskundigen dreigen de kleur van hun omgeving aan te nemen. Hun specifieke meerwaarde gaat daardoor verloren.
\end{abstract}

\section{Ervaringen, ervaringskennis, ervaringsdeskun- digheid}

Een ervaringsdeskundige is iemand die persoonlijke ervaringen met en collectieve kennis over ontwrichting professioneel inzet ten behoeve van anderen. Daarbij gaat het niet alleen over ervaringen met die ontwrichting zelf. Vooral de manier waarop je ermee om moet gaan, ze kan inpassen in het dagelijks leven en/of moet ontgroeien, en hoe adequaat (en met eigen regie) met professionele hulpverlening om moet worden gaan, zijn bouwstenen voor ervaringskennis. Ontwrichting is een algemene noemer voor bijvoorbeeld psychisch lijden, ziekte, handicap, armoede en crisissituaties. Op de persoonlijke ervaringen kunnen reflecteren en deze kunnen integreren in een collectief verhaal zijn basiscompetenties van de ervaringsdeskundige. De eigen doorleefde processen en de collectieve kennis daarover bieden handvatten - en een hoopvol perspectief - bij het coachen van anderen die een (uit)weg zoeken in soortgelijke situaties.

Het expliciet inzetten van ervaringskennis, waaronder persoonlijke ervaringen, onderscheidt erva-

\footnotetext{
W. Boevink (ه)

Vereniging voor Ervaringsdeskundigen (VvEd) en User Research Center, Trimbos-instituut, Utrecht, Nederland
} wboevink@trimbos.nl ringsdeskundigen van hun niet-ervaringsdeskundige collega's. Ervaringsdeskundigen zijn werkzaam in de geestelijke gezondheidszorg, verslavingszorg, maatschappelijke opvang, jeugdhulp, ouderenzorg en de chronisch zieken- en gehandicaptenzorg. Ook werken ze in het sociale domein en in de hulpverlening aan mensen in armoede. Inzicht in de aantallen ervaringsdeskundigen ontbreekt.

\section{Doel of middel?}

Ervaringsdeskundige inzet is nooit een doel op zich geweest, maar vooral bedoeld om de kloof tussen de systeemwereld waarin mensen 'cliënten' of 'patiënten' worden en de leefwereld van deze mensen te verkleinen. Het is een middel in de transitie van de systeemwereld waarin hulpverleners opereren. Eindgebruikers van zorg- en welzijnsorganisaties zijn niet gebaat bij veerkracht ondermijnende, aanbodgestuurde, bureaucratische bolwerken. Zij hebben behoefte aan aansluitende, steunende netwerken, die kunnen meebewegen met de grilligheid van het dagelijks leven en met hun voortdurend veranderende behoeften aan steun. Ervaringsdeskundige bemoeienis vergroot de kans op invloedrijke kruisbestuiving.

\section{Professionalisering van de ggz-ervaringsdeskun- dige}

De geestelijke gezondheidszorg loopt voorop wat betreft de betaalde inzet van ervaringsdeskundigen. Daar is het fenomeen 'ervaringsdeskundigheid' onlosmakelijk verbonden met het hoopgevende concept herstel. Herstel verwijst naar een persoonlijk proces van het herwinnen van veerkracht na een psychische crisis. Het is niet hetzelfde als genezing. Mensen kunnen tijdens hun herstel nog steeds symptomen hebben, maar zijn met gepersonaliseerde steun in 
staat om een nieuw en betekenisvol leven op te bouwen.

Bekostiging door zorgverzekeraars vormt een probleem. Het streven is dit op te lossen met de invoering van een nieuw financieringsstelsel na 2020. Deze ontwikkeling, maar ook de toenemende inzet van ervaringsdeskundigheid bij het uitvoeren van de Wmo 2015, maken beroepsontwikkeling en -registratie relevant. Daar horen beroepscompetentieprofielen en deskundigheidbevordering bij. Opleidingen van ervaringsdeskundigen komen onder meer voort uit de cliëntenbeweging. Daarnaast hebben enkele mbo- en hbo-opleidingen ervaringsdeskundigheid opgenomen in het curriculum, soms als een aanvullende competentie (bij opleidingen Sociaal werk) en soms als een beroepsopleiding.

\section{De paradox}

Als voorzitter van de Vereniging voor Ervaringsdeskundigen ( $\mathrm{VvEd}$ ) zie ik in de vele dossiers die ik onder ogen krijg de 'paradox van professionalisering' terug. De huidige beleidsontwikkelingen bieden kansen die we willen benutten. We willen professionaliseren en vaste grond onder de voet krijgen in zorg en welzijn. We willen meer vrije ruimte voor maatjescontacten of peer support en we streven naar een invloedrijke kruisbestuiving in de transities die gaande zijn. We zijn volledig bereid tot het expliciteren van de meerwaarde van onze expertise en het creëren van transparantie wat betreft de manier waarop die meerwaarde wordt vormgegeven en tot stand komt. Ook initiëren we samen met anderen de ontwikkeling van een beroepsregister met bijbehorende beroepscodes, profielen en opleidingseisen.

Tegelijkertijd zien we als VvEd hoe maatjescontacten worden binnengezogen in een systeem waarin ze door beknottende protocollen hun essentie dreigen te verliezen. Onderlinge steun en zelfhulp komen in het huidige systeem onvoldoende tot hun recht. Ook is er de riskante verleiding bij werkgevers om ervaringsdeskundigen in te zetten tegen de groeiende schaarste op de zorgmarkt bij een krimpend budget. Zonder contextuele en organisatorische veranderingen - meedraaien in het huidige systeem - is dat niet meer dan dweilen met de kraan open.

\section{Kansen vergroten, risico's verkleinen}

Om de kansen te vergroten en de risico's te verkleinen is versterking van het ervaringsdeskundig perspectief nodig, opdat helder wordt waar we voor staan. De focus van de VvEd zal bij individuele ervaringsdeskundigen de komende tijd vooral moeten liggen op het versterken van een gevoel van verbondenheid. Dat ze zich onderdeel weten van een beweging die ertoe doet, waardoor ze zich gedragen voelen, met intensieve netwerken waarop ze in lastige momenten kunnen terugvallen. Zo'n collectieve gedragenheid maakt ervaringsdeskundigen weerbaar in het behoud van hun exclusieve beroepsidentiteit. En dan lukt het wellicht nog beter om onze kritische visie op de huidige ggz om te zetten in effectieve bijdragen aan zorginnovaties richting een duurzame, op herstelsteun gerichte zorgomgeving. 